\title{
Corporate Governance Practices in Senegalese Microfinance Institutions
}

\author{
Mamadou Fadel Diallo', Jean-Pierre Gueyie ${ }^{2, ~ *, ~ M a h m o u d o u ~ B o c a r ~ S a l l ~}{ }^{1}$ \\ ${ }^{1}$ Faculty of Economics and Management, Cheikh Anta Diop University, Dakar, Senegal \\ ${ }^{2}$ School of Management, University of Quebec in Montreal, Montreal, Canada
}

Email address:

mamadouf.diallo@ucad.edu.sn (Mamadou F. D.), gueyie.jean-pierre@uqam.ca (Jean-Pierre G.),

mahmoudou.sall@gmail.com (Mahmoudou B. S.)

${ }^{*}$ Corresponding author

\section{To cite this article:}

Mamadou Fadel Diallo, Jean-Pierre Gueyie, Mahmoudou Bocar Sall. Corporate Governance Practices in Senegalese Microfinance Institutions. European Business \& Management. Vol. 7, No. 3, 2021, pp. 61-71. doi: 10.11648/j.ebm.20210703.12

Received: May 8, 2021; Accepted: May 25, 2021; Published: June 9, 2021

\begin{abstract}
The objective of this paper is to analyse the corporate governance practices in Senegalese microfinance institutions (MFIs), in order to judge their effectiveness. The question is whether in this microfinance setting, governance structures are well implemented and function as well as in conventional firms. In the MFI's literature and specifically in an African environment, there are not too much studies assessing the state of corporate governance practices. This paper aims to provide insights, using the Senegalese MFIs' setting. To reach this end, a survey is conducted over a sample of 99 MFIs. The exploratory factor analysis is used to measure our constructs, from a sand of items collected through a questionnaire. Once the constructs are built, a factorization is performed, and the Cronbach's Alpha $(\alpha)$ allows us the judge the effectiveness of the axes obtained. The results indicate that: - Board of directors (BODs) in Senegalese MFIs are characterized by a plurality of roles. These include a disciplinary, as well as an advisory role. - The composition of BODs in Senegalese MFIs and their mode of operation meet the optimality requirements. - Finally, the BODs in Senegalese MFIs display traits of competency, through two dimensions which are the general competence and the knowledge of the external environment. The practical implications of our results is that Senegalese MFIs have well-functioning BODs. Then being MFIs does not prevent adherence to the best corporate governance practices. The existence of well-functioning BODs should translate into improved financial and social performances.
\end{abstract}

Keywords: Governance, Microfinance Institutions, Best Practices, Senegal

\section{Introduction}

Microfinance is today a real financial industry. In recent years, it has been marked by major crises throughout the world and particularly in Africa. In Senegal, BCEAO reports [6] have shown that many Microfinance Institutions (MFIs) do not respect the rules of conduct, do not release reliable information to the public and are not subject to enough control. As a result, they have highly risky portfolios and they constantly face repayment problems. Losses in such situation are mostly attributed to governance issues.

Much published work on governance focuses on publicly traded companies, explaining to a large extent how its mechanisms protect investors. There are however researchers who are interested in non-listed companies and specifically, in MFIs. These include [25, 44, 45, 47, 48, 50, 51, 60]. Most of the work on governance that focus on the financial sector in general and the microfinance sector in particular try to assess the impact of some governance dimensions (practices) on performance $[44,60]$. There are not too much studies that assess the state of governance in a given environment.

Thus, drawing on the work of Karoui, Khlif and Ingley [42], the objective of this paper is to evaluate the effectiveness of governance practices in Senegalese MFIs.

For a long time, governance has been approached from a disciplinary point of view, playing the role of controlsanction-reward. The current trend is to move away from this black box logic of the Board of Directors (BODs) and to reconsider the role of directors, who can no longer limit 
themselves to simply guaranteeing good conduct [15]. They also have an advisory role towards the management team.

The results are that: - Board of directors (BODs) in Senegalese MFIs are characterized by a plurality of roles. These include a disciplinary, as well as an advisory role. The composition of BODs in Senegalese MFIs and their mode of operation meet the optimality requirements. - Finally, the BODs in Senegalese MFIs display traits of competency, through two dimensions which are the general competence and the knowledge of the external environment.

The rest of the paper is structured as follows. Section 2 reviews the literature and develops our research hypotheses. The third section is devoted to the methodology. Results are presented in Section four and discussed in the fifth section. The conclusion follows in the sixth section.

\section{Theoretical Framework and Research Hypotheses}

The notion of corporate governance originated from the United States, in a context where company directors, with lot of power, faced a dispersed shareholder base [5]. Since then, it has become very popular both in theory and in practice. There are several definitions of corporate governance: For Jensen and Meckling [39], the system of governance is defined as "the means by which financial investors in general and shareholders in particular can ensure the profitability of their investment". Shleifer and Vishny [58] define the field of corporate governance as the study of the processes by which capital providers (reduced to the sole providers of financial capital) guaranteed the profitability of their investment. As for Charreaux [14], governance is "the sand of organizational mechanisms that have the effect of delimiting the powers and influencing the decisions of managers, in other words, that govern their conduct and define their discretionary space". Charreaux and Desbières [16] shows a preference for this definition, as opposed to that [58] because they consider it to be broader. Other theorists describe Charreaux's definition as too general, arguing that it only concerns large firms and is therefore not suitable for MFIs [25]. For this reason, they agree with the definition of Rock and al. [55] who see governance as a process used by the BOD to help an institution fulfill its mission and protect its assets over time.

\subsection{Roles of the Board of Directors}

Several research and reports have been published codifying the role and functioning of the BOD. The board must emphasize oversight of discretionary management behaviour and look out for the interests of shareholders. Karoui and Khlif [41] in a research on the forms of activation of the BOD in SMEs have shown through an exploratory study that the characteristics of the BOD depend on the configuration of the roles it assumes. They have shown that the BOD in SMEs plays four essential roles, namely:

1) The oversight-control role: this role demonstrates the ability of the board to review and monitor the financial statements and accounts of the company. It also includes monitoring the performance of the management team and their compensation;

2) A strategic leadership management role: this involves the appointment (or removal) of board members as well as members of the management team;

3) A strategic advisory role: this role focuses on the conception of strategic policies and the implementation of strategic plans;

4) A service and support role: it indicates the directors' commitment to the company's reputation and to acting as intermediaries with its environment. They provide access to more information and resources.

These four areas demonstrate the BOD's commitment to ensuring the security of shareholders' investments. The control exercised by the BOD is a disciplinary role that ensures compliance with the standards imposed on managers. However, incentive and sanction mechanisms are used by the BOD to oblige managers to adhere to the rules of conduct imposed by the owners. The role of the BOD is not limited to ensuring compliance with the rules of good conduct. It is also their responsibility to guide the entity on the basis of strategic decisions. These decisions are therefore taken in perfect mastery of the company's environment and operations. This is the reason why Karoui and Khlif [41] integrate the notion of directors' knowledge as a key variable in the analysis of governance mechanisms and, above all, as an asset that board members can use to fully play their role.

Other authors have also proposed a categorization of the roles of the BOD from their research perspective, resulting in classifications that differ from those of [41].

Raghavan [54] suggests three main roles to the BOD:

1) A supervisory role consisting in planning, monitoring and evaluating the performance of the Chief Executive Officer (CEO) and the management team, hiring and firing the CEO. The Board must also be able to verify the accuracy and reliability of financial statements, review and determine the total compensation of senior management, and ensure compliance with ethics rules and laws;

2) A a strategic role consisting in studying and improving the mission of the company as well as the overall strategic direction; help mobilize the resources needed to implement strategies and ensure the efficient use of these resources;

3) A leadership role consisting in advising and guiding senior management, particularly the CEO, but also in assessing its own effectiveness.

Golberg and Palladini [30] also identifies four roles that are:

1) Support the mission and objectives of the organization;

2) Guide the major strategic directions of the organization;

3) Ensure the long-term health of the organization and mitigate risks;

4) Install a sense of responsibility throughout the organization.

These different roles assigned to the BOD can be 
synthesized into two levels according to [34, 35]: a financial control level and a strategic control level. Financial control is exercised on the basis of accounting documents ex-ante through the budgand and ex-post through the summary financial statements. Strategic control, on the other hand, refers to the strategy proposed by the firm's manager and the conformity of decisions with the strategy adopted by the BOD. Following this reflection, we formulate the following hypothesis:

H1: The BOD of MFIs are characterized by a plurality of roles exercised by the board

\subsection{Composition and Operation of the BOD}

Board variables are important factors in research on optimal boards. They are measured through the size of the board [38], the proportion of independent directors [63], the duality of function between Chairman of the BOD and the Chief Executive officer [4, 42], the feminization of the board [1], the number of employee directors [62], and the frequency of meetings [42].

\subsubsection{The Size of the Board}

Board size is a critical variable in governance system. According to the resource dependence theory, the board is essential to acquiring external funding or accessing a wide range of knowledge. In this view, larger board put together many directors who can collectively help generate more external resources as well as providing diversified expertise to executive officers [19]. De Andres and Vallelado [22] have reported an inverted U-shaped relation between bank performance and board size. The addition of new directors is positively related to performance, but at a diminishing marginal rate. There is a point at which adding a new director reduces bank value. For their sample, this point is around 19 directors. The positive relation between performance and board size is also found in several studies, including [19, 2, 9, $28,3]$.

However, board with too many members may lead to problems of coordination, control and flexibility in decision making, as well as to a free rider behavior of some directors. Coordination and communication problems arise because it is more difficult to arrange board meetings, and to reach consensus, leading to slower and less-efficient decisionmaking [38]. As board size increases, directors' free-riding also increases because of the stowaway behavior of some directors. They do not properly exercise their oversight role, relying on the others to do it. As consequence, large boards give excessive control to the $\mathrm{CEO}$, harming performance. Thus, advocacy for a limited number of directors on the board. Lipton and Lorsh [46] suggest a size of the board limited to a maximum of 10 directors, with 8 or 9 been the optimal. Jensen [38] argues that the optimum board size should be around seven to eight directors.

Several authors have reported a negative effect of board size on financial performance $[64,18,33]$. Godard [32] and Tchakoute-Tchuigoua [60] show an absence of links between size and performance. To sum up, researchers' results are not unanimous.

\subsubsection{Independent Directors}

The search for the optimal BOD had lead researchers to favor a board composed of independent members. The second Viénot report [63] describes a director as independent "when he or she has no relationship of any kind whatsoever with the company or its group that could compromise the exercise of his or her freedom of judgment". The basic assumption of the agency theory is that the effectiveness of the board increases with the proportion of independent directors. For Bessire et al. [11], the use of independent directors is a source of "adherence to the norm". Boards that do not have independent directors may have difficulty complying with the standard. Beasley [7], Andriamasy et al. [4], and Souid and Stepniewski [59] abound in the same direction, showing that the proportion of independent directors reinforces the role of the board as a mechanism for controlling management. Indeed, the more independent external directors on the board, the more effective the disciplinary role of the board is. Independent directors oppose the most questionable decisions, unlike internal directors recruited among the employees, who have difficulty opposing the decisions of their hierarchical superior.

Cadbury's [12] reports require that all companies have independent members on their boards and that they have a minimum of three members. In the second Viénot report [63], the proportion of independent directors proposed is at least one third of the board members.

Beside independence, Andriamasy et al. [4] also stress the expertise of directors as a determining and beneficial element through the positive synergy effects it has on the board. Directors' expertise is measured by seniority but also by their financial competence. It is important, according to them, to also have a significant proportion of independent directors on the audit committee. "The presence of directors who are not salaried employees but who should bring their experience, their competence, their economic, social, and legal" approaches to the board is a source of synergy for the board [62].

\subsubsection{Duality of Function}

This variable refers to the join holding of the positions of CEO and Chairman of the BOD. Some research emphasizes the separation of these functions as a means of improving the Board's control capacity. Their combination could represent a risk for creditors insofar as it allows the executive to easily defend the projects he has initiated and implemented, even if they are not beneficial to shareholders. It is inconceivable that a Chairman of the BOD would sanction itself as a CEO [38]. According to the agency theory, this accumulation of functions increases the laxity of managers and their opportunistic behaviour. This is why it strongly recommends the separation of the two functions. According to [38], "for the BOD to be effective, it is important to separate the functions of chairman and chief executive officer". The same arguments are advanced by [50]. According to him, effective 
governance requires a clear separation between these functions.

The BOD sets the major strategic orientations and ensures that effectiveness is monitored, while the CEO is responsible for initiating and implementing the strategy. Therefore, giving the chairman and CEO statutes to a single person means giving him more power and weakening the power of the board.

\subsubsection{The Feminization of the Board}

The promotion of women in decision-making bodies is a topical issue today. In some countries in the world, public authorities are enacting laws concerning the promotion and integration of a significant percentage of women in all sectors and at the highest levels of decision-making.

Regarding the BOD, much has been written on the importance of the feminization of BOD [8, 13, 1]. Some papers point to a positive relationship with the performance, while others conclude a lack of connection or even a negative connection.

The work of Belghiti-Mahut and Lafont [8] and Sabatier [57] shows that the presence of women on the board is a source of greater performance. Campbell and Minguez Vera [13] and Sabatier [57] go in the same direction. Greater board gender diversity could improve corporate governance by increasing the independence of the board from executive management and providing better control over the management of the company.

However, the results are mixed, as other empirical studies find a negative impact of the number of women on the BOD on financial performance [1]. An explanation to this result can be the fact that women are largely underrepresented on boards compared to their place in societies [43]. Since they often remain a large minority on boards, they would not be in a position to influence strategic decisions. This problem has been highlighted by [13], using Spanish data. They show that it is not the presence of women on boards that improves performance, but rather the rate of feminization.

\subsubsection{Functional Variables}

These variables seek to open the black box of BODs by using psycho-sociological elements. The BOD is thus considered to be a decision-making team or group playing an active role [23]. The first variable relates to the regularity of meetings and the second to the quality of reporting procedures. Indeed, the regularity of meetings improves the flow of information between the organization and the board on one hand. On the other hand, it reduces the asymmetry of information that is the foundation of the agency's theory [39]. Diop [24] reported a positive effect of the frequency of board meetings on improving the level of execution in savings and credit mutuals. Pugliese and Winstop [53] showed a positive relationship between the functioning of the BOD and their contribution to strategic decision-making. Regular evaluation procedures have a positive and significant effect on the involvement of BOD in the decision-making process. Karoui, Khlif and Ingley [42] showed that there is a positive relationship between the mode of operation of the board and its performance. Indeed, "the frequency of meetings implies the maintenance of a sufficient level of information to allow directors to be active and involved". These authors argue that the frequency of meetings develops a sense of belonging among directors and consequently a sense of duty towards their company. Based on all the above arguments, our second hypothesis is as follows:

H2: the composition and functioning of the Senegalese MFI's BOD are optimal

\subsubsection{Competency Variables}

Competence, generally defined as the compromise of three elements: knowledge, know-how and soft skills, is used in most governance research as an important factor in measuring board effectiveness. Perrin [52], Vecchio [62], Dardou et al. [21], Karoui, Khlif and Ingley [42], etc. have all shown the importance of variables related to competence in explaining a board that is able to defend the interest of stakeholders. These variables are used in the cognitive logic of governance where knowledge sharing is considered as a fundamental source of additional value creation beneficial to the BOD. According to Charreaux [15], it is the preferred mechanism in the cognitive approach. Vecchio [62] argues that in BODs there is a need of competence, knowledge, expertise, know-how and experience. Among these criteria, the BOD needs above all, competence. Perrin [52] finds that competence increases the relationship of trust and it is rather explained through the expertise of the directors. Andriamasy et al. [4] measure directors' expertise by seniority and financial competence. Seniority shows the capitalization of a certain experience and develops the knowhow of board members. This thesis therefore shows how important it is to have a board composed of members who have capitalized on a certain experience. Karoui, Khlif and Ingley [42] demonstrated a positive relationship between competencies, collective board knowledge, and performance. They studied knowledge from both internal and external aspects, and competence is assessed in a rather general way. Diop [24] measures competency through the items of directors' education level, seniority and management knowledge. He finds an absence of link between competence and mutual penetration, which is one of the measures of financial performance.

Other researchers base board performance on a mix of general and specific knowledge. General knowledge relates to the different functions of the firm, whereas specific knowledge relates to firm's products and markets [27].

The importance of board members' mastery of environmental aspects is also acknowledged. Today's companies evolve in a changing environment, marked by permanent crises and on this basis information must be collected for management decisions that adjust for realities. This leads Ong and Wan [49] to conclude on the need to control their environment.

These arguments on competence lead us to the following third hypothesis:

H3: The BODs of MFIs display some level of competence 


\section{Data and Methodology}

\subsection{The Variables}

To evaluate the involvement of the BOD in the functioning of MFIs, certain governance practices are measured by constructs developed on the basis of items identified and validated by $[41,42]$. These constructs and items are presented in the following Table 1.

The other variables on the composition and functioning of the BOD will be measured in several ways using both binary, ordinal and mean measurement variables. Board composition variables will be measured by the traditional governance variables, namely size, number of independent directors, board chair person/CEO duality and gender.

The functional variables will be measured through the frequency of meetings, the duration of meetings, evaluation of the board and informal meetings of the board members.

Table 1. Constructs and items.

\begin{tabular}{|c|c|c|}
\hline Constructs & Items & Definition \\
\hline \multirow{4}{*}{ Monitoring-Control (MC) } & $\mathrm{MC1}$ & Involvement of directors in auditing the accounts \\
\hline & MC2 & Involvement of directors in monitoring the MFI's performance \\
\hline & $\mathrm{MC} 3$ & Involvement of directors in the control of management teams \\
\hline & $\mathrm{MC4}$ & Involvement of directors in the fixation and control of the remuneration of the management team \\
\hline Strategic Leadership & SLM1 & Involvement of directors in the appointment of the BOD \\
\hline Management (SLM) & SLM2 & Involvement of directors in the appointment of co-directors \\
\hline \multirow{3}{*}{ Support Service (SS) } & SS1 & Directors actively participate in the management of the MFI's reputation and image \\
\hline & SS3 & Directors collect information on changes in the environment \\
\hline & SS4 & Directors actively contribute to obtaining certain strategic resources (financial, technological, etc.) \\
\hline \multirow{3}{*}{ Strategic Role (STR) } & STR1 & Directors discuss strategic alternatives \\
\hline & STR2 & Directors participate in the choice of a strategy \\
\hline & STR3 & Directors discuss strategic action plans \\
\hline \multirow{10}{*}{ Competence (COMPE) } & COMPE1 & Degree of knowledge of the general environment by board members \\
\hline & COMPE2 & Degree of knowledge of the competitive environment by board members \\
\hline & COMPE4 & Degree of knowledge of the MFI's products and services by board members \\
\hline & COMPE5 & Degree of knowledge of the MFI's organization by board members \\
\hline & COMPE6 & Degree of knowledge of the MFI's culture by board members \\
\hline & COMPE7 & Degree of presence of the manager's competence on the BOD \\
\hline & COMPE8 & Degree of presence of scientific expertise on the board \\
\hline & COMPE9 & Degree of financial expertise on the BOD \\
\hline & COMPE10 & Degree of presence of legal expertise on the board \\
\hline & COMPE11 & Degree of technical competence of board members \\
\hline
\end{tabular}

\subsection{Collecting Data}

The data used in this paper were collected through a closed form questionnaire that was administered by professional interviewers. We used a 5-point Likert scale [ranging from 1 to 5 , with 1 being the lowest and 5 the highest]. This method is used by many governance researchers [62, 41, 42, 24]. The MFIs surveyed are those that have a BOD or a staff group which is not specifically called BOD, but which fully plays its role. This indication is useful because sometimes in MFIs a steering committee that plays the role of BOD may have a different name. To broaden our sample we decided to include it in the list of respondents, where it exists. 120 questionnaires were sent to respondents, of which we received 99 , or $82.5 \%$ valid one. For data processing we used SPSS software.

\subsection{Methodology}

\subsubsection{Constructs Building}

The approach used to measure the constructs in this paper is the exploratory factor analysis. Its objective is to extract the latent factors (i.e., the constructs) from a sand of items collected through the questionnaire, so as to restore the maximum amount of information [10]. We used the orthogonal rotation method. In general there are four orthogonal rotation methods: equamax, orthomax, quartimax and varimax, the most frequently used being varimax [31]. The Kaiser, Meyer and Olkin (KMO) test and the Bartlett sphericity test allow us to ensure that the data we have are suitable to run factor analysis. Indeed, the KMO test indicates the extent to which the sand of selected items is a coherent sand and that it allows us to constitute one or more adequate measures of concepts. A high KMO indicates that there is a statistically acceptable factorial solution that represents a relationship between the items. If it is less than 0.5, then the items do not have enough variance to be analyzed. On the other hand, if the KMO is greater than 0.5 and closer to 1 , then factor analysis is possible.

Bartlett's test tests the absence of correlation hypothesis. At 5\% threshold, the null hypothesis is rejected if the P-value is smaller than 0.05 . In this case the variables are correlated. It is therefore possible to consider factorization.

These tests are carried out in this research and allow us to pass from items to the constructs. 


\subsubsection{Judging the Effectiveness of the Dimensions of the BOD Retained}

The correlation measures as well as the factorization of variables among themselves are not sufficient for the identification and acceptance of a dimension. Indeed, in addition to these tests, it is necessary to ensure the coherence of the items within each dimension but also of the model as a whole. Therefore Cronbach's Alpha $(\alpha)$ test becomes necessary.

Cronbach's Alpha $(\alpha)$ is an indicator that assesses the reliability of the items that are supposed to measure a phenomenon. It provides information on the extent to which each item correlates with at least one other item. In addition, it is "an indicator that gives an estimate of the proportion of the total variance due to all common factors reflected in the statements rather than to specific items" [10]. Reliability depends on the degree of interrelationship (correlation, covariance) between the statements. According to [26] in an exploratory study, a Cronbach's alpha between 0.6 and 0.8 is acceptable. The closer it is to one (1), the better the internal consistency of the scale. On the contrary, the closer it is to zero (0), the less internally consistent the scale is.

The alpha coefficient can be considered as the average of the alpha coefficients that would be obtained for all possible combinations of two subsets of the items measuring the same concept.

This test was carried out to judge the effectiveness of the explanatory dimensions of the roles of BOD in the MFIs. The results are presented below.

\section{Results}

\subsection{Descriptive Statistics}

Table 2 shows the distribution of the MFIs surveyed, by their legal status. It indicates that in majority, they are mutual and credit unions (MCU) [69.70\%].

Table 2. Statistics on the MFIs surveyed, by legal status.

\begin{tabular}{llll}
\hline & Frequency & Percentage & Cumulative percentage \\
\hline LLC & 6 & 6.10 & 6.10 \\
PLC & 12 & 12.10 & 18.20 \\
MCU & 69 & 69.70 & 87.90 \\
NGO & 12 & 12.10 & 100.00 \\
TOTAL & 99 & 100.00 & - \\
\hline
\end{tabular}

Source: from our survey data.

LLC=Limited Liability Company; PLC=Public Limited Company; MCU=Mutual and credit unions; NGO=Non- government organization.

Although with NGO, these MCU constitute $81.80 \%$ of the sample, we note the emergence of limited liability companies (LLC and PLC) which represent $18.2 \%$ of the sample. The emergence of these for-profit institutions is often presented as a proof of mission drift, i.e., the quest for profitability before social objectives.

Table 3 shows that $74 \%$ of the MFIs surveyed are affiliated to a network. Network generally plays a fundamental role in the MFIs' functioning. It is put in place not only to provide affiliated MFIs with the support they need, but also to group together some functions with a view to optimizing management. We can cite among others: orientation of the general strategy of the network, cash management, risk management, insurance, information and communication technology, international operations.
Table 3. Membership in networks (affiliation to a network).

\begin{tabular}{llll}
\hline & Frequency & Percentage & Cumulative percentage \\
\hline YES & 74 & 74.70 & 74.70 \\
NO & 25 & 25.30 & 100.00 \\
TOTAL & 99 & 100.00 & - \\
\hline
\end{tabular}

Source: from our survey data.

Table 4 shows descriptive statistics on BOD's characteristics. The average size of the BOD is 14 members. $86 \%$ of the MFIs surveyed stated that they have independent directors on their board. On average, we have about 5 independent directors on the board. $79.8 \%$ of the sample MFIs, responded that their Chairman of the BOD is not the same person as the Chief Executive Officer. This indicates a clear separation of these two functions.

Table 4. Descriptive statistics on BOD characteristics.

\begin{tabular}{|c|c|c|c|c|c|}
\hline & No & Mean & Std. Deviation & Min & Max \\
\hline Age of the MFI (year) & 87 & 12 & 5.98 & 1 & 28 \\
\hline Number of directors on the board & 87 & 14 & 5.40 & 5 & 19 \\
\hline Number of independent directors on the board & 87 & 5 & 2.47 & 2 & 11 \\
\hline Number of female directors & 87 & 6 & 2.88 & 2 & 13 \\
\hline Frequency of BOD's meetings & 87 & 8.32 & 1.74 & 4 & 10 \\
\hline Length of BOD's meetings (hour) & 87 & 4.81 & 1.61 & 2 & 8 \\
\hline Age range of BOD's members (year) & 87 & 47 & 5.39 & 35 & 60 \\
\hline Statement & & & & Yes & No \\
\hline The MFI has independent directors on the board & & & & $86.00 \%$ & $14.00 \%$ \\
\hline The MFI has female directors on the board & & & & $100.00 \%$ & $0.00 \%$ \\
\hline
\end{tabular}




\begin{tabular}{|c|c|c|}
\hline Mean & Std. Deviation & Max \\
\hline The chairman of the BOD is also the CEO & $20.20 \%$ & $79.80 \%$ \\
\hline The MFI has a female manager & $32.30 \%$ & $67.70 \%$ \\
\hline The decision to hire a BOD member is based on its seniority in the microfinance industry & $73.70 \%$ & $26.30 \%$ \\
\hline Our board members sit on the BOD of other companies & $39.40 \%$ & $60.60 \%$ \\
\hline Members of the BOD are assiduous at the meetings of the board & $84.80 \%$ & $15.20 \%$ \\
\hline Our BOD hold informal meetings & $90.90 \%$ & $09.10 \%$ \\
\hline
\end{tabular}

Source: from our survey results.

The respondents unanimously confirm the presence of women on their board, with an average proportion of $43 \%$ of the board members. In addition, $32.3 \%$ of the MFIs in the sample are headed by women.

Regarding the recruitment of board members, $73.7 \%$ of the respondents stated that they base their decision on the seniority of the members in the microfinance industry and $39.4 \%$ preferred those who sat on other boards.

For meetings, we note that they last on average 5 hours for 8 sessions in the year. That is, every 1.5 month, the BOD holds a formal meeting to decide on the functioning of the institution. This seems good and allows it (the board) to closely follow the evolution of the institution. $84.8 \%$ of the members are on average assiduous at the meetings of the board. This shows their commitment and therefore their duty towards the institution.

Informal meetings seem to be frequent. $90.9 \%$ of the members confirm that they have recourse to these forms of meetings, apart from the formal ones. These meetings have been shown in previous research to be beneficial for the functioning of the BOD. The average age of BOD members is 47 , and their average duration term is 7 years.

\subsection{Roles of the BOD}

Table 5 presents the factorial axis of the roles of BODs. Two dimensions stand out in our context.

Table 5. The factorial axes of board's roles.

\begin{tabular}{|c|c|c|c|c|}
\hline Items & Axis 1 & Axis 2 & Cronbach Alpha $(\alpha)$ & Variance explained \\
\hline STR1 & 0.773 & & & \\
\hline STR2 & 0.885 & & 0.809 & $41.3 \%$ \\
\hline STR3 & 0.878 & & & \\
\hline $\mathrm{CS} 2$ & & 0.694 & & \\
\hline CS3 & & 0.851 & 0.727 & $27.3 \%$ \\
\hline CS4 & & 0.847 & & \\
\hline \multirow{2}{*}{\multicolumn{3}{|c|}{ Precision measurement of the Kaiser-Meyer-Olkin sample }} & & 0.657 \\
\hline & & & Chi-Two approximate & 183.80 \\
\hline \multirow{2}{*}{\multicolumn{3}{|c|}{ Bartlett test of sphericity }} & Degree of freedom & 15 \\
\hline & & & Meaning of Bartlett & 0.000 \\
\hline \multicolumn{3}{|c|}{ Global alpha } & & 0.704 \\
\hline \multicolumn{4}{|c|}{ Global variance explained } & $68.7 \%$ \\
\hline
\end{tabular}

Source: from our survey results.

These are the strategic role (axis1) and the control oversight- role (axis 2). We note that the model used to evaluate these dimensions meets scientific standards both in the structure of the factors and in the consistency of the model. All our alphas are in the range defined by [26]. The explained variance is significant. The KMO is high and Bartlett's sphericity tests are significant.

As far as the interpretation of the axes is concerned, the grouping of items in two dimensions gives:

Dimension 1 (axis 1): measures the strategic role of the BOD in discussing strategic alternatives, in their participation in the choice of a strategy, and in the discussion of action plans for the implementation of the strategies chosen. This dimension corroborates the theory of absolute rationality, which is generally composed of these three successive phases and leads to optimal results.

Dimension 2 (axis 2): measures the control role of the BOD. It includes items measuring the degree of involvement of directors in the control of the management teams, the degree of control of the management teams and the degree of control of the remuneration of the management team. These variables implement the disciplinary role that directors have over the management team.

\subsection{Competence}

Table 6 presents the communalities of competence items, and Table 7, its factorial axis.

Table 6. Communalities of competence items.

\begin{tabular}{lll}
\hline Items & Initial & Extraction \\
\hline COMPE1 & 1.000 & 0.576 \\
COMPE2 & 1.000 & 0.740 \\
COMPE3 & 1.000 & 0.792 \\
COMPE6 & 1.000 & 0.628 \\
COMPE9 & 1.000 & 0.780 \\
COMPE10 & 1.000 & 0.760 \\
COMPE11 & 1.000 & 0.825 \\
\hline
\end{tabular}

Extraction method: Principal axis factoring. Rotation method: varimax.

As far as the interpretation of the axes is concerned, the grouping of the items in two dimensions gives:

Dimension 1 (axis 1): includes items COMPE6, COMPE9, 
COMPE10 and COMPE11. It measures the general competences of BOD members, which we call global competence. It is necessary or even indispensable in MFIs that directors have skills in both the financial and legal fields because of the specificity of the industry. Dimension 1 explains $54 \%$ of competence.

Dimension 2 (axis 2): measures the external knowledge of the board members. This dimension includes items COMPE1, COMPE2 and COMPE3, and explains 19\% of competence. Its weight is relatively low compared to the global competence. The Cronbach alpha are respectively 0.882 and 0.748 for the first and second dimension, with an overall alpha of 0.854 .

Table 7. The factorial axes of competence.

\begin{tabular}{lllll}
\hline Items & Axis 1 & Axis 2 & Cronbach Alpha $(\boldsymbol{\alpha})$ & Variance explained \\
\hline COMPE6 & & & $54 \%$ \\
COMPE9 & 0.728 & & 0.882 & \\
COMPE10 & 0.863 & & & $19 \%$ \\
COMPE11 & 0.871 & 0.579 & 0.748 & 0.812 \\
COMPE1 & 0.886 & 0.857 & & 341.97 \\
COMPE2 & 0.870 & Chi-Two approximate & 21 \\
COMPE3 & & Degree of freedom & 0.000 \\
Precision measurement of the Kaiser-Meyer-Olkin sample & Meaning of Bartlett & 0.854 \\
Bartlett test of sphericity & & & $73 \%$ \\
Global alpha & & & \\
Global variance explained & & & \\
\hline
\end{tabular}

Source: from our survey results.

\section{Discussion of Results}

Karoui, Khlif and Ingley's work [42] has highlighted four main roles played by the $\mathrm{BOD}$, namely a strategic role, a strategic leadership role, a control and monitoring role, and finally a service and support role. These roles are present in the BOD studied by the author and are exercised very seriously.

In our study, two of these roles are present. These are the strategic role and the control role. The two remaining roles are not significant in our context. Nearly half of board members discuss strategic alternatives and more than $90 \%$ claim to be involved in the choice of strategies and the development of action plans. This shows the extent to which MFIs' BOD are involved in the definition and implementation of strategies in their institutions. The sharing of knowledge and discussion of alternatives are fundamental to this approach and are found in our study to a significant degree.

More than $80 \%$ of the board members claim to be involved in performance monitoring but also in the monitoring of the management team. On the other hand, $76.8 \%$ are interested in controlling the remuneration of this team.

The fact that the MFIs in our sample are not limited to the traditional disciplinary role, but also emphasize the strategic role validates our hypothesis H1: the BOD in Senegalese MFIs are characterized by a plurality of roles exercised by the board. It plays a control role, but also a strategic role.

The average number of board members in Senegalese MFIs is 14 . In the sense of $[38,46]$, these MFIs have mostly large BODs. This situation may favor stowaways. For this paper, the most important is the presence of a BOD in the surveyed MFIs, with sufficient number of directors.

The presence of independent members on the board is one of the most important factor in determining board performance. As we have learned from the literature, it is a positive signal for channeling the opportunistic behavior of managers. The use of independent directors is beneficial for an effective board. Independent directors oppose decisions by management that tend to harm the interests of shareholders. Research has shown that they not only reduce conflicts of interest but also reduce agency costs. They are beneficial for the BOD if the number reaches $1 / 3$ of the total number of besiegers [63]. Kanter [40] considers a critical threshold of $35 \%$ for a social group to be able to influence decisions. The results of our research show that the average number of independent directors is effectively $35 \%$ of the members who sit on the board. In the sense of [40, 63], independent directors in our MFIs are well represented. From these findings we can say that the number of independent directors in our sample is optimal.

The duality of functions is also an important lever for deciding on the optimal composition of the BOD. This variable contrasts the thesis of independence (which defends a clear separation of the functions of CEO and Chairman of the BOD) with the thesis of the unity of command defended by the theory of stewardship (which advocates the accumulation of the two functions). According to the first thesis (i.e., the thesis of independence) defended by $[17,38$, $50,56]$, it is quite unlikely that a Chairman of the BOD (CBOD) would sanction himself as a CEO. This increases the laxity of managers and ultimately results in performance losses. The second thesis defended by $[32,61]$ considers that the accumulation of functions could be beneficial to shareholders. The results of our research show that $80 \%$ of respondents support the thesis of independence. From these results, it can be clearly stated that the majority of MFIs are aware of the risks of uniqueness and opt for the separation of 
the two functions. This translates into a positive signal in governance practices.

In addition, we note a strong female presence on the BOD, on average $46 \%$, contrary to the work of [42], on French SMEs. The rate of feminization is, according to some researchers, a strong signal of good governance practices. However, not all researchers agree on the effects of the high rate of feminization on board decisions. Adams and Ferreira [1] consider that BOD need female directors who unfortunately are rare to find. For these authors, female directors are those with proven skills, who impose themselves in male-dominated groups and identify themselves through the right decisions. These women have a positive impact on performance, otherwise they only harm it.

In the sense of the reports by $[12,63]$ and the research by $[20,36,37]$, we can conclude that the composition of the board meets the optimality requirements. Indeed, the size of the BOD is on average satisfactory, and the percentage of independent directors is optimal. We note a clear separation of the key functions of the CEO and the CBOD in the majority of MFIs and a fairly high rate of feminization.

The regularity of meetings as confirmed in the literature improves the flow of information and reduces information asymmetry, but also makes it possible to monitor objectives. It is recommended in best managerial practice to monitor objective indicators through partial analyses to guide the entity as it drifts off course. This should not be done by waiting for the annual results, but by monitoring the realization at midterm in order to take corrective action if necessary. The frequency of meetings (once every 1.5 month) and the high attendance rate of members (85\%) imply "maintaining a sufficient level of information to enable directors to be active and involved" [23]. We can say that directors have a sense of belonging that may explain their strong involvement and duty to the MFI.

In light of these results, we can say that our hypothesis $\mathrm{H} 2$ is confirmed. Therefore, the composition of the BOD and their mode of operation meet the optimality requirements.

The work of Karoui, Khlif and Ingley [42] gives a measure of the concept of BOD competencies through three dimensions: external knowledge, internal knowledge and general competencies. Among these dimensions, two are present in ours paper, i.e., the general competence and the knowledge of the external environment. We do not validate the internal knowledge dimension. Items related to this dimension such as COMPE4, COMPE5, COMPE7 and COMPE8 were eliminated during the factorization. The knowledge of MFI's culture by the members of the board (COMPE6) is present, but is instead included in the general competence dimension. It is entirely conceivable to associate the knowledge of MFI's culture with general competence. When directors sit on a BOD, they are expected to be the first to be imbued with the MFI's ideology, values, rituals, etc. All these elements are included in the corporate culture.

Having identified two relevant dimensions of competence in Senegalese MFI's, we can conclude that our hypothesis H3 is partially validated [42]. Then, Senegalese MFI BODs display some level of competence.

\section{Conclusion}

The objective of this paper is to analyze governance practices in Senegalese MFIs, in order to judge their effectiveness. To do so, we formulated three hypotheses, that we tested using data collected through a field survey.

Concerning the role played by the BOD, we note that Senegalese BODs in MFIs play two main roles: the traditional disciplinary role of the BOD and a strategic advisory- role towards the management team. The disciplinary role is strongly felt in the exercise of their control function. Described in the literature as the primary role of the BOD, this dimension is very present in the answers to our survey. The mechanisms through which the disciplinary role is exercised are the size of the board, the absence of dualism of functions and the representation of women on the board, all of which meet the conditions for optimality. The percentage of independent directors also meets the conditions for optimality in the sense of [40, 63]. This leads us to conclude that the composition of the boards of Senegalese MFIs meets the optimality requirements.

The strategic function is also present in the MFIs studied. This dimension seems to have the same importance than the control dimension. Our results mark a break with the classical preponderance given by agency theory to the disciplinary role of corporate governance.

Competence, is considered in the cognitive approach as a major lever that solidifies knowledge sharing. According to the literature, the competence dimension is a well-known and highly explanatory variable of cognitive governance [15]. The competencies of Senegalese BODs are highlighted in this paper, through two dimensions: the general competence and the knowledge of the external environment.

Overall, the results of this study are consistent with the literature on the components of optimal BOD. The findings show that governance practices are effective in Senegalese MFIs in the sense of the good practices recognized by theorists and practitioners. Being MFIs (legal form and their field of intervention) does not prevent them to adhere to the best corporate governance practices. The presence of wellfunctioning BODs in Senegalese MFIs should theoretically translate into improved financial and social performances. Is this observed in practice? Future researches should try the related BOD' characteristics and various measures of performance.

\section{References}

[1] Adams, R. B., and Ferreira, D. (2009). Women in the boardroom and their impact on governance and performance. Journal of Financial Economics, 94 (2), 291-309.

[2] Adams, R, and Merhan, H. 2005. Corporate performance, board structure and its determinants in the banking industry. Working paper. Federal Reserve Bank of New York. 
[3] Abdel-Azim, M. H., and Soliman, S. (2020). Board of directors' characteristics and bank performance: Evidence from the Egyptian banking sector. Journal of Governance and Regulation, 9 (4), 116-125.

[4] Andriamasy, V., and Rakota, P. (2008). Les mécanismes de gouvernance et l'amélioration de la pertinence de l'information comptable. Revue Française de Gouvernance d'Entreprise, 4 (2), 59-87.

[5] Bancel, F. (1997). La gouvernance des entreprises. Edition Economica 112 pages.

[6] BCEAO. (2010). Guide méthodologique du contrôle interne des SFD dans les pays de la zone UEMOA. IRAM.

[7] Beasley, M. S. (1996). An empirical analysis of the relation between the board of director composition and financial statement fraud. The Accounting Review, 71, 443-465.

[8] Belghiti-Mahut, S., and Lafont, L. (2009). Présence des femmes dans le top management et performance financière des entreprises: une étude exploratoire. $20^{\text {ème }}$ Congrès Annuel de l'Association Francophone de Gestion des Ressources Humaines, Toulouse.

[9] Belkhir, M. (2009). Board of directors' size and performance in the banking industry. International Journal of Managerial Finance, 5 (2), 201-221.

[10] Benraiss, L. (2004). Méthodologie de construction d'une échelle de mesure: application du paradigme de Churchill. Communication présentée lors du 15ème congrès de l'Association Francophone de Gestion des Ressources Humaines. Montréal, 1-4 septembre 2004.

[11] Bessire, D., Chatelin-Ertur, C., and Onnée S. (2008). Les normes de gouvernance et effet d'universalisation le cas de l'administrateur indépendant et pratique et en théorie. Revue Française de Gouvernance d'Entreprise, 4 (2), 9-31.

[12] Cadbury, R. (1992). Report of the committee on financial aspects of corporate governance. London, Gee and Co Ltd.

[13] Campbell, K., and Minguez Vera, A. (2010). Female board appointments and firm valuation: short and long term effects. Journal of Management and Governance, 14 (1), 37-59.

[14] Charreaux, G. (1997). Le gouvernement des entreprises: corporate governance, théories et faits. Paris, Economica. 540 pages.

[15] Charreaux, G. (2004). Corporate governance theories: from micro theories to national systems theories. Cahier du FARGO (1040101) Version révisée.

[16] Charreaux, G., and Desbrières, P. (1998). Gouvernance des entreprises: valeur partenariale contre-valeur actionnariale. Finance, Contrôle, Stratégie, 1 (2), 57-88.

[17] Chouchane, I. (2010). Les déterminants de la présence des administrateurs indépendants dans le conseil d'administration des sociétés françaises. Revue des Sciences de Gestion, 245246, 63-71.

[18] Coles, J. L., Daniel, N. D., and Naveen, L. 2008. Boards: does one size fit all? Journal of Financial Economics, 87, 329-356.

[19] Dalton, D., Daily, C., Johnson, J., and Ellstrand, A. 1999. Number of directors and financial performance: A metaanalysis. Academy of Management Journal 42, 674-686.
[20] Daily, C. M., and Dalton, D. R., (2005). Boards of directors: utilizing empirical evidence in developing practical prescriptions. British Journal of Management, 16, 91-97.

[21] Dardour, A., Husser, J., and Ouvrard, S. (2014). Information financière et modèles de gouvernance: le point de vue des experts comptables stagiaires. Revue des Sciences de Gestion, Direction et Gestion, 267-268, 123-128.

[22] De Andres, P., and Valledo. E., (2008). Corporate governance in banking: The role of the boards of directors. Journal of Banking and Finance, 32 (12), 2570-2580.

[23] Demb, A., and Neubauer, F. F. (1992). The corporate board, confronting the paradoxes. Oxford University Press. 224 pages.

[24] Diop C. M. (2010). Gouvernance et performance et financière des MEC du Sénégal: le rôle du conseil d'administration. Mémoire DEA FASEG UCAD.

[25] Djaowe, J. (2013). Gouvernance et crise des IMF au Cameroun. Vèmes journées internationales de la Microfinance Douala «mutations et crises de la microfinance».

[26] Evrard, Y., Pras, B., and Roux, E. (2003). Market : Études et Recherches en Marketing. $3^{\text {eme }}$ Édition. Dunod.. 720 pages.

[27] Forbes, D. P., and Milliken, F. J. (1999). Cognition and corporate governance: understanding boards of directors as strategic decision making groups. Academy of Management Review, 24, 489-505.

[28] Fratini, F., and Tettamanzi, P. 2015. Corporate governance and performance: evidence from Italian companies. Open Journal of Business and Management 3 (2), 199-218.

[29] Godard, L. (2001). Taille du conseil d'administration: déterminants et impact sur la performance. Cahier du FARGO n 1010702- 27 pages.

[30] Golberg, M., and Palladini, E. (2011). Gestion des risques et création de valeur avec la microfinance. Edition Eska, 202 pages.

[31] Durand, C. (2005). L'analyse factorielle et l'analyse de fidélité: notes de cours et exemple. Université Montréal département sociologie.

[32] Godard, L., and Schatt, A. (2004). Caractéristiques et fonctionnement des conseils d'administration français: un état des lieux. CUREGE, Université de Fanche-Comité Normes et Mondialisation, France.

[33] Guest, P. M. 2009. The impact of board size on firm performance: evidence from the UK. The European Journal of Finance, 15 (4), 385-404.

[34] Gupta, A. K. (1987). SBU strategies, corporate-SBU relations and SBU effectiveness in strategy implementation. Academy of Management Journal, 30, 477-500.

[35] Hoskisson, R. E. (1989). Multidivisionnal structure and performance: the contengency of diversification strategy. Strategic Management Journal, 30 (4), 625-644.

[36] Huse, M. (2000). Boards of directors in SME's: a review and research agenda. Entrepreneurship and Regional Development, $12,271-290$.

[37] Huse, M. (2005). Corporate governance: understanding important contingencies. Corporate Ownership and Control, 2 (4), 41-50. 
[38] Jensen, M. (1993). The modern industrial revolution, exit, and the failure of internal control systems. Journal of Finance, 48 (3), 831-880.

[39] Jensen, M. C., and Meckling, W. H. (1976). Theory of the firm: managerial behavior, agency costs and ownership structure. Journal Financial Economics, 3 (4), 305-360.

[40] Kanter, R. M. (1977). Men and women of the corporation. New York: Basic Books.

[41] Karoui, L., and Khlif, W. (2007). Formes d'activation des conseils d'administration dans les PME. Une étude exploratoire dans le contexte français. AIMS XVIème Conférence Internationale de Management Stratégique.

[42] Karoui, L., Khlif, W., and Ingley, C. (2009). Les déterminants «traditionnels» de la performance des conseils d'administration ont-ils encore du sens dans les PME ? Une étude exploratoire dans le contexte français. Working paper.

[43] Koubaa, H. B. A. (2014). Qualité de la communication financière au sujet des pratiques de bonne gouvernance d'entreprise: cas du SBF 120. Comptabilités, Économie et Société, Montpellier: France version 1.

[44] Koudou, Z. O.; Okou, W. M., Zokou, G. R.; Odessi, A. O., and Kouadio B. A. (2014). Gouvernance des institutions de microfinance et leurs performances en Côte d'Ivoire. Forum Innovation VI-Edition 2014 Crise, innovation et transition Octobre.

[45] Lapenu, C. (2002). La gouvernance en microfinance: grille d'analyse et perspective de recherche. Revue Tiers Monde, XLIII (172), 847-865.

[46] Lipton, L., and Lorsch, J. (1992). A modest proposal for improved corporate governance. The Business Lawyer, 48, 5977.

[47] Ndiaye, M. M. (2012). La gouvernance des organisations de microfinance rurales au Sénégal: analyse historique et institutionnelle des mutuelles et coopératives du REMEC NIAYES. Thèse doctorat en sciences économiques université Montesquieu.

[48] Ngendahayo, E. (2008). Statut juridique, gouvernance et performance des institutions de microcrédit: Une étude empirique sur les données du MIX (Micro finance Information Exchange). Université de Lille II GERME-ESA 1 place Déiot 59000 Lille. (Chapitre 4 de la thèse: Microcrédit et Théorie Financière).

[49] Ong, C. H., and Wan, D. T. (2001). Board structure, board process and board performance: a review and research agenda. Journal of Comparative International Management 4 (1), 7095.

[50] Onomo, R. (2015). Gouvernance dans les institutions de microfinance: contingence et apprentissage organisationnel. Consortium pour la Recherche Economique et Social (CRES) 2015/73.
[51] Périlleux, A. (2009). La gouvernance des coopératives d'épargne et de crédit en microfinance: un enjeu de taille. Reflets Perspectives de la Vie Économique, 2009/3, XLVIII. 51-60.

[52] Perrin, C. (2008). Une explication de la gouvernance des ONG vue à travers les processus de rationalisation de l'aide humanitaire. Dossier spécial: 7ème Conférence internationale de Gouvernance d'entreprise (CIGE), Bordeaux, Revue Française de Gouvernance d'Entreprise, 4, 159-180.

[53] Pugliese, A., and Winstop, P. Z. (2007). Board members contribution to strategic decision-making in small firms. Journal of Management and Governance, 11 (4). 383-404.

[54] Raghavan, P. (2009). Management stratégique. Edition du renouveau pédagogique Inc. 332 pages.

[55] Rock, R., Otero, M., and Saltzman, S. (1998). Principles and practices of microfinance governance. MBP Project, Development Alternatives Inc. (DAI), August.

[56] Sall, M. B. (2013). Gouvernance des systèmes financiers décentralisés et financement de l'activité économique: cas du PRODAME (Projet de développement agricole de la région de Matam). African Management Studies, 1 (2), 96-124.

[57] Sabatier, M. (2014). Féminisation des conseils d'administration et performance des entreprises. Recherche effectuée dans le Cadre d'une convention conclue entre l'Institut de Recherches Économiques et Sociales (IRES) et la CFE-CGC.

[58] Shleifer, A., and Vishny, R. W. (1997). A survey of corporate gouvernance. Journal of Finance 52, (2). 737-783.

[59] Souid, S., and Stepniewski, J. (2010). Rôle du conseil d'administration et gestion des résultats. Revue des Sciences de Gestion, Direction et Gestion, 234-244, 35-41.

[60] Tchakoute-Tchuigoua, H. (2010). L'influence des mécanismes de gouvernance sur la performance des institutions de microfinance d'Afrique Sub-saharienne. CEB Recherche Institute in Management Science, (10/026).

[61] Van den Berghe, L. A. A, and Levrau, A. (2004). Evaluationg boards of directors: what constitutes a good corporate board? Corporate Governance: an International Review. 12 (4), 461478 .

[62] Vecchio, N. (2008). Dans quelle mesure la diversité au sein du conseil d'administration améliore-t-elle la gouvernance de l'entreprise ? Etude exploratoire sur les entreprises du CAC 40. Dossier spécial: 7ème Conférence internationale de gouvernance d'entreprise (CIGE), Bordeaux, Revue Française de Gouvernance d'Entreprise, 4, 83-204.

[63] Viénot, M. (1999). Rapport du comité sur le gouvernement d'entreprise, $A F E P-M E D E F$.

[64] Yermack, D. 1996. Higher market valuation of companies with a small board of directors. Journal of Financial Economics, 40, 185-221. 